\title{
Communication technologies, Covid-19 and core-competence of the tourism enterprises
}

\section{Komunikacione tehnologije, Covid-19 i osnovna kompetencija turističkih preduzeća}

\author{
Jelena Premović ${ }^{1}$, Slavoljub Vujović ${ }^{\star}$, Dijana Jovanović ${ }^{3}$, Dejan Jovanović ${ }^{4}$ \\ 1,2Institute of Economics, Belgrade, Serbia / Ekonomski institut, Beograd, Srbija \\ ${ }^{3,4}$ Dositej College, Belgrade, Serbia / Visoka škola Dositej, Beograd, Srbija \\ ${ }^{*}$ Corresponding author / Autor za prepisku
}

Received / Rad primljen: 05.12.2020, Accepted / Rad prihvaćen: 12.05.2021.

\begin{abstract}
Having in mind the growing importance and role that ICT have in improving the quality of the tourist offer, it is very important that employees in the tourism industry constantly monitor the trends of change in this area and to continuously train and improve in this technological sphere.

The aim of research is to point out the importance and possibilities of applying information and communication technologies (ICT) in tourism enterprises as a factor in improving quality the tourist offer.
\end{abstract}

Keywords: information and communication technologies, tourism offer, enterprises, human resources.

Sažetak: Imajući u vidu sve veći značaj i ulogu koju IKT imaju u poboljšanju kvaliteta turističke ponude, veoma je važno da zaposleni u turističkoj industriji neprestano prate trendove promena u ovoj oblasti i da kontinuirano treniraju i usavršavaju se u ovoj tehnološkoj sferi.

Cilj istraživanja je da se ukaže na značaj i mogućnosti primene informaciono-komunikacionih tehnologija (IKT) u turističkim preduzećima kao faktora za poboljšanje kvaliteta turističke ponude.

Ključne reči: informacione i komunikacione tehnologije, turistička ponuda, preduzeća, ljudski resursi.

${ }^{1}$ orcid.org/0000-0002-7932-853X, e-mail: jelena.premovic@gmail.com

2orcid.org/0000-0002-0686-3486, e-mail: kelovic1967@yahoo.com

3orcid.org/0000-0001-7236-6931, e-mail: dijana.jovanovic@gmail.com

${ }^{4}$ orcid.org/0000-0002-9091-4003, e-mail: dejan.jovanovic@akademijadositej.edu.rs

\section{INTRODUCTION}

Technological development is directly related to the intellectual capital i.e., the human factor, because it is the most important development resource nowadays. Investing in the intellectual capital development is a global tendency, because the 'civilisation of knowledge' is important for all countries, regardless of their development level. Intellectual capital as the company's intangible assets include: experience, information, know-how, managers' readiness, brand, image, reputation, culture, consumer loyalty, trust, knowledge of consumer preferences and the ability to process information (Sagić, et. al, 2019).

The concept of the knowledge society puts the human personality, his knowledge with the application of information technologies, supported by computer networks and the Internet, at the center of events (Arsić, Premović, 2020). 
The ability to innovate is one of the important factors of change and success, which is why innovation is a necessity for the survival and vitality of enterprises, but also of national economies and society as a whole. Improvement of existing and introduction of new products and services can be achieved through systematic and continuous implementation of innovation and learning processes in enterprises (Cvijanović and other, 2018). Knowledge and effective management of organizational knowledge encourages the creativity of employees, which is achieved through various innovations (Premović, 2021). To maintain a market position and achieve a competitive advantage, innovations are necessary primarily in the management system (forecasting, planning, organization, control, rewarding employees for the achieved results, etc.), (Vujović, 2018).

The importance of information technology (IT) in modern business is enormous. Based on the presented research of a group of authors (Sagić et.al, 2019) advanced economies accounted for $85-88 \%$ of the global top $1 \%$ in $1988-2005$, falling to $77 \%$ in 2012. There was a decline in global inequality from 2005 to 2012. Global wealth data show rising participation of emerging economies in the global elite. The tendency towards globalisation generally requires open organistic forms, based on modern technology and modern knowledge.

Researching the consequences of the COVID-19 pandemic on tourist trends, in the context of a broader analysis of political and economic trends in the world, concludes that all crises and major social problems in the world are related to tourism and the economy. It would be an epochal undertaking to define guidelines for the development of tourism that could serve as a model for overcoming the consequences of the COVID-19 pandemic applicable to all countries and nations. The serious negative effects of the COVID19 pandemic on tourism trends are confirmed by reports from the World Tourism Organization (UN WTO). The analysis of the latest trends, according to UNWTO statistics, confirms that international tourist travel in 2020 decreased by $20 \%$ to $30 \%$ compared to 2019 due to the COVID-19 pandemic (International Tourist Arrivals, 2020).

The analysis of the impact of COVID-19 on tourism revenues, based on UNWTO statistics, shows that the reduction of tourist trips by $20-30 \%$ in 2020 compared to 2019, amounts to 300 to 450 billion US dollars, which is one third of the revenues in 2019.

Tourism is now one of the five largest export industries in over 150 countries, while in 60 countries it is the number one export. For $1 / 3$ of developing countries and of $1 / 2$ the least developed countries, tourism is the main source of foreign exchange (Premović, Pejanović, 2016).
Tourism suffered the greatest crisis on record in 2020 following an unprecedented health, social and economic emergency amid the outbreak of the COVID-19 pandemic (UNWTO, 2021). According to the UNWTO statistic data, international tourist arrivals (overnight visitors) plunged by $74 \%$ in 2020 over the previous year due to widespread travel restrictions and a massive drop in demand. As the result of the COVID-19 pandemic, the loss of USD 1.3 trillion in export revenues was estimated in 2020. That is more than 11 times the loss recorded during the 2009 global economic crisis. Based on the overall analysis and calculation, the COVID-19 pandemic has put between 100 and 120 million direct tourism jobs at risk.

\section{LITERATURE REVIEW}

In turbulent conditions with rapid change, modern enterprises gain a competitive advantage in the market based on the so-called core competence. The core competence is the main source of competitive advantage, and it is built only through the learning process, because only foreground generated as a result of the learning process, predominantly affects the creation of added value in today's market (Premović, 2016).

If enterprises want to successfully perform their activities, they must adapt their organizational structure and culture and encourage the practical application of the concept of continuous (lifelong) learning and education from various fields, especially in the field of information and communication technologies. Therefore, it is necessary, as Todosijevic (2016) points out, to identify leading organizations capable of constructive technological improvements and the introduction of innovations and the formation of an engineering scientific and technical base.

In order to improve business management and positioning in the market, business and social organisations take advantage of available information technologies. IT includes not only modern hardware technology but also techniques, methods, models, platforms and processes (Sagić, et.al, 2019).

The necessity that tourism constantly monitors technical and technological, cultural and other changes in order to ensure adequate and timely knowledge of the characteristics of tourist demand while adapting the tourist offer to the new needs of tourists, this confirm the role and importance of human resources in tourism. Three basic elements or factors of tourism development are: human resources, space and material basis, where human resources are the first and main factor of development (Vujović, 2018, and others). Although in the literature are present thinking (especially geographers) that space is prime element in tourism 
development, the reality that space without the presence of human remains just a place exposed to the natural processes challenge such opinions. Meaning that designated area by human work can be made more interesting to visit and can be arranged certain tourist offer. Therefore, it must build infrastructure as one of the basic elements of the material basis. So, the man in best case the educated and professional human resources identify and evaluate natural and anthropogenic values of the area and build in it infrastructure systems, create the material basis of tourism, based on which it is organized specific tourist offer (Vujović, Premović, Grujić, 2014).

Under the influence of intensive technological development and globalization, the pronounced complexity and dynamism of the tourist market initiated changes in the structure of tourist supply and demand (Vujović, Cvijanović, Štetić, 2012). The complexity of the tourist activity fuels the constant need to take new actions in order to adapt the tourist product to the requirements of the tourist demand by recognizing the needs of tourists, their realization and appearance on the tourist market (Vujović at al. 2011).

One of the basic goals of the scientific and technological development policy is the new knowledge creation, transfer, mastering and diffusion. The purpose of learning is to increase knowledge or to achieve a higher level of existing skill. In this regard, learning relates to a relatively constant change in behaviour that arises as a result of experience or practice (Sagić, et. al, 2019; Janković i ostali, 2020). In performing tourism activities and providing tourist highquality services, continuous training and education of human resources has a particularly important role. Therefore, tourism companies must allocate additional funds for intensive staff training (the rule of successful companies becomes that each employee should spend some time in the "classroom"). The more sophisticated the services provided by tourism companies, with more built-in knowledge, the longer the mandatory time spent in education. Managers are estimated that they need to spend over a fifth of their working time in their own education, in order to prevent „knowledge obsolescence“. This means that the useful life of knowledge is getting shorter, so that one can no longer live from the „old glory“, ie. knowledge acquired in an earlier period (Milenković, 2009).

Although interdisciplinarity is present in the programs of human resources education for work in the tourism industry in the light of economic and geographical approach, ie, the study of tourism from the aspect of geography and economy, there is very little multidisciplinarity and transdisciplinarity, which should be seriously expanded (Vujović, Premović, Grujić, 2014).
Based on the analysis and forecasts of government organizations in charge of monitoring the development of tourism and economic tourism organizations in twenty European countries, the problem of lack of ICT- electronic informatics in the tourist offer, (as opposed to the demand for tourism) is recognized as one of the significant problem in this area. As a weakness of information and communication technologies, some authors point out the impossibility of transferring experience. "The combination of livestreaming technology and tourism is an important development in the evolution of tourism experiences. Research on live-streaming tourism is becoming popular, but empirical studies on the relationship between live streaming and travel intention remain underexplored“" (Zhang, et al., 2021:56). Weaknesses and limitations of Live streaming, which is characterized by interaction and takes the form of a small community, according to other authors (Chen and Lin, 2018).

\section{METHODOLOGY}

The basic premise on which is based this paper is that ICT and educated and trained human resources is the most important intangible business asset, which affects the quality of tourism services.

To determine the real situation in tourist companies in Serbia and to determine whether ICT knowledge is used and in what way, an original survey was conducted. The importance of the Internet in the function of the quality of the accommodation offer of a particular tourist destination has also been investigated.

In this research were applied: the method of induction and deduction, the method of analysis and synthesis method, deductive and comparative methods, as well as techniques of structured questionnaire for field research. The obtained data were processed in SPSS program.

Based on the results of the original research conducted within the tourism enterprises on the territory of Serbia, it can be concluded that Internet and IC technologies are not sufficiently exploited and market-verified through competitive tourist advantages within the tourist activity on the territory of Serbia.

\section{HUMAN REOSURCES AND ICT IN THE TOURISM INDUSTRY IN SERBIA}

Recent research has recognised that technological factors are not the only key to the effectiveness of the information technologies acceptance. Research findings confirm that the basic factors of an online trust model are: website usability, privacy, security, expected product performance, loyalty, and electronic management of customer 
relations. The results in the study of financial performance of 594 enterprises that operate within the ICT industry in Serbia in the period of five years (2009-2013) and their dependence on IC efficiency indicated that human capital and physical capital partially affect financial performance, which is consistent with empirical findings from other developing countries. When compared to other industries in Serbia, ICT industry demonstrated more significant impact of human capital (Sagić et.al, 2019).

\section{RESULTS AND DISCUSSION}

In order to determine the importance of the Internet in the function of the quality of the accommodation offer of a particular tourist destination in Serbia, a primary quantitative survey was conducted which included a total of 220 respondents of which 144 respondents $(65.5 \%)$ were male and 76 respondents $(34.5 \%)$ were female (Cvijanović et al., 2019).

Primary quantitative and qualitative research was conducted in Belgrade. The main goal of the research is to examine the relationship between sociodemographic variables (gender, age, level of education, work status, monthly personal income of respondents) and the frequency of Internet use by respondents and the purpose for which it is used.

The independent variables in this research were: gender, age, level of education of the respondents, employment status of the respondents and monthly personal income of the respondents. Dependent variables examined the frequency and purpose of Internet use, with respondents on a five-point Likerttype scale assessing the extent to which they agreed with the statements examined, where 1 meant I did not completely agree and 5 meant I completely agreed.

The conducted research showed the existence of a connection between socio-demographic variables (gender, age, level of education, work status, monthly personal income of the respondents) and the frequency of Internet use among the respondents.

The results show that respondents use the Internet every day (4.57), mostly because of e-mail (4.46) and web search (4.39), and least because of E-banking (3.28) and shopping (3.52).

Multiple regression examined whether the combination of predictors, which included gender, age, employment status, level of education and monthly personal income of respondents, could predict the frequency of Internet use and the purpose for which respondents use it.
The obtained results show that younger, more educated respondents with higher monthly incomes and a larger number of household members use the Internet more than other groups of respondents for the purpose of education. Based on the results, it can be concluded that highly educated men with higher personal incomes more than other respondents tend to always be online.

On the other hand, younger unemployed respondents living in households with a smaller number of members use the Internet more than other categories of respondents for information and entertainment. Based on the results, it can be concluded that employed respondents who live in households with a larger number of members use E-banking more than other categories of respondents.

The results show that younger lower-educated employed respondents with higher personal incomes use the Internet more before buying more than is the case with other categories of respondents in order to inform about the total offer and prices. Based on the results, it can be concluded that the comments of other users have a greater impact on younger lower educated men with higher monthly household incomes and fewer household members who earn income than on other categories of respondents.

The results show that younger employed women with lower education with higher monthly personal incomes and a larger number of household members have the most experience in shopping online. Based on the results, it can be concluded that lower educated respondents with a larger number of household members prefer to shop online more than other groups of respondents and do so whenever possible.

Only some of the presented research results, such as the results that respondents use the Internet every day mostly for e-mail and web search, and least for E-banking and shopping, that younger respondents use the Internet more for shopping compared to other groups of respondents but also that the most experienced in shopping online have younger employed women with lower education with higher monthly personal income and more household members - confirm the basic assumption of the author that the possibilities of applying ICT and especially Internet technology in tourism enterprises in Serbia are not used adequately and that there is significant space for further improvement of the quality of the tourist offer in Serbia in this context (Premović, 2021).

In order to determine the basic characteristics of human resources in Serbian tourism and determine whether continuous human resource management 
through the prism of applying the concept of lifelong learning and education is applied to achieve competitive advantages of tourism companies in Serbia, an original empirical study was conducted. Primary research performed within the framework of the doctoral dissertation Premović (2015).

The study involved 141 respondents: 89 men and 52 women. The largest number of 71 respondents has a university degree, while the pred- ominant age structure of respondents is between 33-40 years of age, which is a total of 71 .

All respondents are employed in companies, tourism organizations, agencies, institutions and other legal and natural persons in Serbia directly and/or indirectly participate in the creation of the tourist offer and the provision of tourist services. The SPSS program was used for processing and analysis of the obtained data.

Table 1 - Sample structure - respondents who participated in the research by gender, education and age

\begin{tabular}{|l|l|c|c|}
\hline Variable & Number & $\%$ \\
\hline \multirow{4}{*}{ Gender } & Male & 89 & 63,1 \\
\cline { 2 - 4 } & Female & 52 & 36,9 \\
\hline \multirow{5}{*}{ Education level } & Secondary school - skilled worker & $/$ & $/$ \\
\cline { 2 - 4 } & College & 52 & 36,9 \\
\cline { 2 - 4 } & College - basic academic studies of the 1st degree & 16 & 11,3 \\
\cline { 2 - 4 } & University - academic studies of the 2nd degree - master & 71 & 50,4 \\
\cline { 2 - 4 } & Master's degree and / or doctorate & 2 & 1,4 \\
\hline \multirow{5}{*}{ Age } & Less than 25 & 3 & 2,1 \\
\cline { 2 - 4 } & From 26 to 32 years & 24 & 17,0 \\
\cline { 2 - 4 } & From 33 to 40 years & 53 & 37,6 \\
\cline { 2 - 4 } & From 41 to 55 years & 40 & 28,4 \\
\cline { 2 - 4 } & More than 56 years & 20 & 14,2 \\
\cline { 2 - 4 } & No answer & 1 & 0,7 \\
\hline
\end{tabular}

Source: Results of the author's original research.

The results of the empirical research showed that the concept of lifelong learning and education is applied in 56 companies $(39.72 \%)$ in which the respondents are employed, while this is not the case in 49 companies, which is equivalent to a percentage share in the basic sample of $34.74 \%$ companies.

A significant number of respondents are not familiar with the educational policy and human resource management strategies in the tourism enterprises in which they are employed. 36 respondents answered that they do not know or are not sure whether the concept of lifelong learning is applied in the company or not.

Research on the application of the concept of lifelong learning and education and new information and communication (IC) technologies conducted in Serbia showed that the concept of lifelong learning and education is applied in $56(39,72 \%)$ companies that employ respondents, while $85 \quad(60,28 \%)$ companies do not apply this concept (Figure 1).

Social networks have replaced the traditional media. Experiences from all over the world indicate the increasing role of platform use in marketing. Decision makers try to identify ways in which firms can make profitable use of applications such as Wikipedia, YouTube, Facebook, Linkedln and Twitter. Live streaming video content will be the emerging trend. Regardless of the great popularity of social networks, top world companies recognise the importance of live interaction between people and do not use technology to replace the need for these interactions. Smart companies use the fact that customers are connected to each other virtually through social networks, but live interaction makes business connections more valuable and stronger (Sagić et.al, 2019).

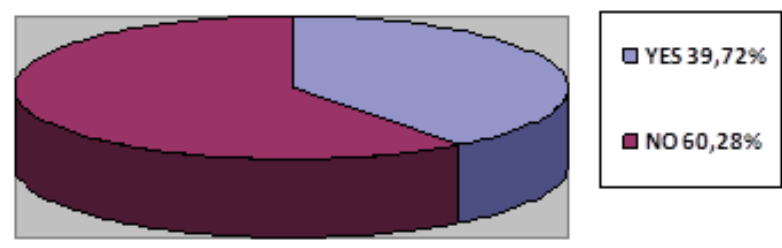

Figure 1 - Application of the lifelong learning concept in the tourism enterprises in Serbia Source: Results of the author's original research.

Based on these facts, it has been also researched about improving knowledge and skills in the 
field of IC technologies the application new information and communication (IC) technologies (Blagojević, et al. 2020). Almost all respondents, more precisely 139 of the 141 who participated in the survey (as can be seen in Table 2), improved their knowledge in the field of information and comm- unication technologies. Certainly, this is an encouraging fact and proof of the understanding of the importance of modern information and communication technologies by tourist companies from the area of Serbia that were included in the research (Premović, 2021).

Table 2 - Improving knowledge and skills in the field of IC technologies

\begin{tabular}{|c|c|c|c|c|c|}
\hline \multirow{2}{*}{\multicolumn{2}{|c|}{$\begin{array}{c}\text { Have you improved your } \\
\text { knowledge } \\
\text { from IC technology? }\end{array}$}} & \multicolumn{2}{|c|}{$\begin{array}{l}\text { In which period did you } \\
\text { improve ICT knowledge? }\end{array}$} & \multicolumn{2}{|c|}{$\begin{array}{l}\text { Do you use the internet and } \\
\text { social networks at work? }\end{array}$} \\
\hline & & \multirow{2}{*}{$\begin{array}{c}\text { During the } \\
\text { last year }\end{array}$} & \multirow{2}{*}{$\begin{array}{c}\text { During the last } \\
\text { three years }\end{array}$} & \multirow{2}{*}{$\begin{array}{c}\text { Internet - yes, } \\
\text { social networks } \\
\text { - not }\end{array}$} & \multirow{2}{*}{$\begin{array}{c}\text { Yes, both the } \\
\text { internet and } \\
\text { social networks } \\
97\end{array}$} \\
\hline YES & 139 & & & & \\
\hline $\mathrm{NO}$ & 2 & 2 & 2 & 2 & 2 \\
\hline
\end{tabular}

Source: Results of the author's original research.

A slightly larger number of a total of 78 respondents improved this knowledge in a period of one to three years, while 61 respondents acquired new knowledge in information technology in a period of up to one year. Only 2 respondents answered that they had not improved their knowledge of IC technologies in the previous three years. The research found that two thirds of the respondents use both the Internet and social networks at work. However, one third uses the Internet, but not social networks in performing tourist activities on the territory of Serbia, which is necessary to change in the coming period.

If tourism industry wants to achive its role as one of key generators of economic development in Serbia (Premović, 2016), it is essential that human resources working in the tourism sector have the knowledge, skills and abilities, as well as to continuously manages their professional training and development.

\section{CONCLUSION}

Having in mind the needs of modern consumer society and the specifics of tourist activity as a highly labor-intensive service activity, it can be concluded that ICT and high-tech equipment and services are of great importance for improving the quality of the tourist offer. Also, there are great opportunities for daily use of high-tech equipment and services, primarily Internet technology in order to improve the quality of accommodation capacities of the tourist destination.

Based on the presented results of research conducted in Belgrade, which showed that the possibilities of using IT and Internet technology are great in the context of improving the quality of tourism, as well as research on the use of ICT by employees in tourism in the Republic of Serbia, it is possible to conclude that the possibilities of using the Internet and IC technologies are not sufficiently exploited and market-verified through competitive tourist advantages within the tourist activity on the territory of Serbia, which is especially necessary to work on in the forthcoming period.

\section{Acknowledgement}

This paper is part of a research project of the MPNTR RS, no. 046001.

\section{REFERENCES}

[1] Arsić, LJ., Premović, J. (2020). Upravljanje znanjem i društvo znanja kao preduslov opstanka i razvoja savremenog društva, Nauka bez granica III: Međunarodni tematski zbornik, sveska 5: Društvo u ogledalu nauke, Filozofski fakultet, Kosovska Mitrovica, Republika Srbija.

[2] Blagojević, M., Papić, M., Garabinović, D. (2020). Business intelligence and open data: The possibi lities for the derivation of valuable information in tourism domain. Hotel and Tourism Management, 8(2), 113-124.

[3] Chen, C.C., Lin, Y.C. (2018). What drives livestream usage intention? The perspectives of flow, entertainment, social interaction, and endorsement. Telematics and Informatics, 35, 293-303.

[4] Cvijanović, D., Vujović, S., Maksimović, G. (2018). Mehanizmi i specifičnosti funkcionisanja ponude i tražnje na turističkom tržištu, Razvojna akademija poljoprivrede Srbije, Beograd.

[5] Cvijanović, D., Vujović, S., Premović, J. (2019). Internet technology in function of the quality of accommodation offer, XX International Scientific 
Conference, Knowledge without borders $(29$ 31 march, 2019), Vrnjačka Banja, Serbia.

[6] International Tourist Arrivals Could Fall by 20$30 \%$ in 2020 , available at:

https://www.unwto.org/news/internationaltourism-arrivals-could-fall-in-2020, (13.03.2021).

[7] Janković, M., Jovanović, L., Krasulja, N. (2020). Značaj informacionih tehnologija u formiranju modela održivog razvoja. Ecologica, 27(98), 240-246.

[8] Milenković, S. (2009). Turizam i ekonomija, monografija, Univerzitet u Kragujevcu, Ekonomski fakultet, Kragujevac.

[9] Premović, J. (2015). Human resources as a strategic potential of sustainable tourism development of Serbia, PhD Thesis, Faculty of Economics, University of Kragujevac.

[10] Premović, J. (2016). Characteristics of human resources in Serbian rural tourism, Economics of Agriculture, 63(2), 633-647.

[11] Premović, J. (2021). Human resources management in tourism companies, monograph, Institute of Economics, Belgrade.

[12] Premović, J., Pejanović, R. (2016). Green economy in the function of sustainable tourism development of Serbia. The First International Scientific Conference: Tourism in function of development of the Republic of Serbia - Spa Tourism in Serbia and Experiences of Other Countries, Faculty of Hotel Management and Tourism in Vrnjačka Banja, 2-4 June, 2016, pp. 394-411.
[13] Sagić, Z., Diković, Lj., Trumbulović, Lj., Vujović, S. (2019). Intellectual capital and leading information technology trends as components of a modern company development, Ekonomika preduzeća, 67(3-4), 288-296, doi: 10.5937/ ekopre1904288s.

[14] Todosijević, R. (2016). Inovativnost kao determinanta poslovnog uspeha, Zbornik radova XXI Internacionalnog naučnog skupa SM2016: Strategijski menadžment i sistemi podrške odlučivanju u strategijskom menadžmentu, (983995), Subotica-Palić.

[15] UNWTO. (2021). World Tourism Barometer and Statistical Annex, January 2021.

[16] Vujović, S. (2018). Turizam u svijetlu ekonomije, Ekonomski institut, Beograd.

[17] Vujović, S., Cvijanović, D., Štetić, S. (2012). Destinacijski koncept razvoja turizma, monografija, Institut za ekonomiku poljoprivrede, Beograd.

[18] Vujović, S., Premović, J., Grujić, B. (2014). Kadrovi u turizmu - specifičnosti obrazovanja kadrova za turizam, Ekonomski vidici, 19(4), 437-447.

[19] Vujović, S., Spaić, J., Vukosavljević, D. (2011), Anatomizovanje turističke tražnje u svetlu ekonomskih zakonitosti, fenomena, efekata i paradoksa u potrošnji, Ekonomika Poljoprivrede, (58)4, 563-576.

[20] Zhang, W., Wang, Y., Zhang, T. (2021). Can "Live Streaming" Really Drive Visitors to the Destination? From the Aspect of "Social Presence", SAGE Open, January-March 2021: 1-13. https://doi.org/10.1177/21582440211006691 